10IKC-359

\title{
PETROLOGY, BULK-ROCK GEOCHEMISTRY, INDICATOR MINERAL COMPOSITION, AND ZIRCON U-PB GEOCHRONOLOGY OF THE END-CRETACEOUS DIAMONDIFEROUS MAINPUR ORANGEITES, BASTAR CRATON, CENTRAL INDIA
}

\author{
N.V.Chalapathi Rao ${ }^{1 *}$, B.Lehmann ${ }^{2}$, E. Belousova ${ }^{3}$, D. Frei ${ }^{4}$, and D.Mainkar ${ }^{6}$ \\ ${ }^{I}$ Centre of Advanced Study in Geology, Banaras Hindu University, Varanasi, 221005, India \\ (Corresponding author: E-mail: nvcr100@gmail.com) \\ ${ }^{2}$ Mineral Resources, Technical University of Clausthal, Clausthal-Zellerfeld, 38678, Germany \\ ${ }^{3}$ GEMOC, Department of Earth and Planetary Sciences, Macquarie University, NSW 2109, Australia \\ ${ }^{4}$ Department of Earth Sciences, Stellenbosch University, Private Bag X1, Matieland, 7602, South Africa \\ ${ }^{5}$ Directorate of Mines and Geology, Chhattisgarh, Raipur-492007, India
}

It was Wagner (1914) who first recognised, based essentially on petrographic grounds, two main sub-groups of kimberlites in the Kaapvaal craton of southern Africa which he termed them as basaltic (mica-poor) and lamprophyric (micarich) varieties. Based on their distinct radiogenic isotopes the basaltic kimberlites have been renamed (Smith, 1983) as Group I (characterised by lesser radiogenic $\mathrm{Sr}$ and more radiogenic $\mathrm{Nd}$ and $\mathrm{Pb}$ ) variety whereas the micaceous variety have been termed as Group II (characterised by more radiogenic $\mathrm{Sr}$ and lesser radiogenic $\mathrm{Nd}$ and $\mathrm{Pb}$ ) variety. Further studies have brought out several distinctions between these two groups in terms of their age, distribution, mineral chemistry, geochemistry and mantle-derived xenoliths and xenocrysts (e.g., Fraser and Hawkesworth, 1992; Mitchell, 1995; Coe et al., 2008; Howarth et al., 2011).

However, recent studies have established unambiguous occurrence of end-Cretaceous orangeites in the Mainpur area of the Bastar craton, Central India (Lehmann et al., 2010; Chalapathi Rao et al., 2011a). In this study, we report new data involving petrology, bulk-rock geochemistry (including Platinium Group of elements), indicator mineral chemistry (garnet, crdiopside and spinel xenocrysts) and U-Pb zircon geochronology of the Behradih, Kodomali, Payalikhand and Kosambura pipes from the Mainpur orangeite field. We also estimate oxygen fugacity $\left(f \mathrm{O}_{2}\right)$ of the Mainpur orangeite magmas by applying $\mathrm{Fe}-\mathrm{Nb}$ oxybarometry to their perovskite chemistry and attempt to assess the role of oxidation state in their diamond grade. The findings of this study provide additional insights into the (i) origin of these pipes, (ii) diamond prospectivity, (iii) nature and composition of the sub-Bastar lithosphere and (iv) in furthering our understanding on the petrological and geochemical differences between the Mainpur orangeites and well studied Mesoproterozoic kimberlites from the Wajrakarur (WKF) and Narayanpet (NKF) fields, Dharwar craton, southern India as well as those from southern Africa.

Preserval of diatreme (Behradih) as well as hypabyssal facies (Kodomali) in this domain imply differential erosion. Behradih samples are pelletal and tuffisitic in their textural habit whereas 


\section{0 $^{\text {th }}$ International Kimberlite Conference, Bangalore - 2012}

those of the Kodomali have inequigranular texture and comprise aggregates of two generations of relatively fresher olivines. The Kosambura pipe displays high degrees of alteration and contamination with silicified macrocrysts and carbonated groundmass and rest others are either not exposed or their samples are not amenable for petrological and geochemical studies. Olivine, spinel and clinopyroxene in the Behradih and the Kodomali pipes share overlapping compositions whereas the groundmass phlogopite and perovskite show conspicuous compositional differences.

In terms of mineral chemistry similarities as well as differences have been noticed between Kodomali and Behradih pipes. Olivine, spinel and clinopyroxene in both the pipes have overlapping compositions whereas the groundmass phlogopite $\left(\mathrm{TiO}_{2}\right)$ and perovskite $\left(\mathrm{Nb}_{2} \mathrm{O}_{5}\right.$ and $\left.\mathrm{Fe}_{2} \mathrm{O}_{3}\right)$ show marked differences. Distinctness in the composition of clinopyroxene of the Kodomali samples of this study and those reported by earlier workers (Fareeduddin et al., 2006) raises the possibility of multiple eruptions within in the same pipe as autoliths of earlier kimberlite intrusions were also recorded (Chatterjee et al., 1994). As multiple kimberlite eruptions (up to 8 ) within a short span of a few million years have been recorded from Prieska region, southern Africa (Smith et al., 1994) and Fort á La Corne field, Canada (Kjarsgaard et al., 2009) radiometric dating on mineralogically distinct samples is in progress to ascertain such episodes within the Kodomali pipe. Nevertheless, mineral compositions of the Behradih and Kodomali pipes together show considerable differences than those from the Mesoproterozoic kimberlites of Wajrakarur Kimberlite Field (WKF) and Narayanpet Kimberlite Field (NKF), southern India and resemble the southern African orangeites in this regard (Fig. 1).

The major element contents viz., $\mathrm{SiO}_{2}, \mathrm{MgO}$, $\mathrm{Fe}_{2} \mathrm{O}_{3}{ }^{*}, \mathrm{~K}_{2} \mathrm{O}$ and $\mathrm{TiO}_{2}$ of the Behraidh and Kodomali pipes are clearly different from bulk of

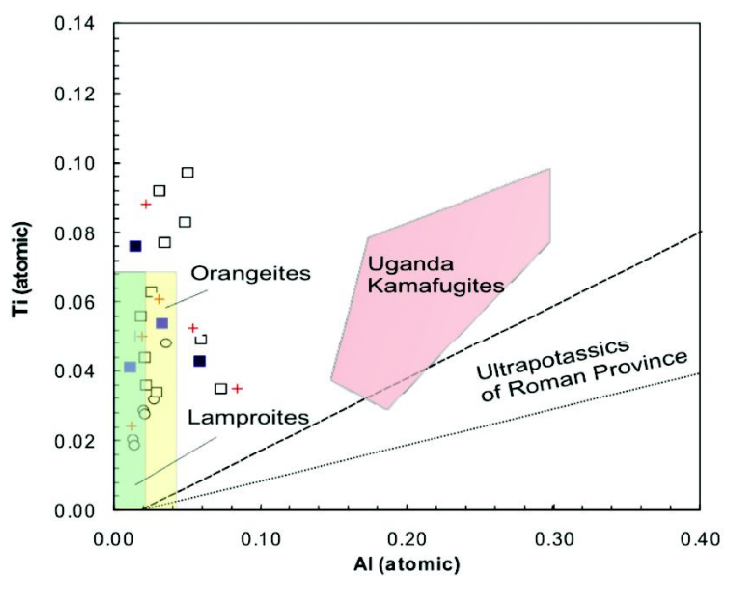

Figure $1 \mathrm{Al}_{\text {total }}$ versus $\mathrm{Ti}_{\text {total }}$ expressed as atoms per formula unit for clinopyroxene for the Kodomali and Behradih. Also shown are the data for clinopyroxene from the Krishna lamproites (open squares) and Narayanpet kimberlites (open circles).

the WKF and NKF which have relatively lower $\mathrm{SiO}_{2}$ and a much wider range in their $\mathrm{MgO}$. Furthermore, when compared to the archetypal kimberlites and orangeites of southern Africa, the Mainpur pipes as well as kimberlites from NKF and WKF clearly display more fractionated nature and show show strong affinities towards those of orangeites (Fig.2A and B). Incompatible element abundances involving elements such as $\mathrm{Ba}, \mathrm{Nb}$, $\mathrm{La}$ and $\mathrm{Rb}$ distinguish the Behradih and Kodomali pipes from a majority of the WKF and NKF kimberlites

PGE in kimberlites are limited with such data reported for only few occurrences from Kapvaal craton, southern Africa, Sao Francisco craton, Brazil and North China craton (e.g., McDonald et al., 1995; Zhang et al., 2010). PGE abundances in both studied Mainpur pipes are indistinguishable thereby implying a similarity in the petrogenesis of their magmas. The PGE contents of the Mainpur orangeites are also similar that of the southern African and Brazilian kimberlites and Mengyin and Fuxian kimberlites from North China craton with slightly lower Rh abundances for some samples (Fig.3).

The pyrope garnet population in the Behradih, Kodomali, Payalikhand and Kosambura 

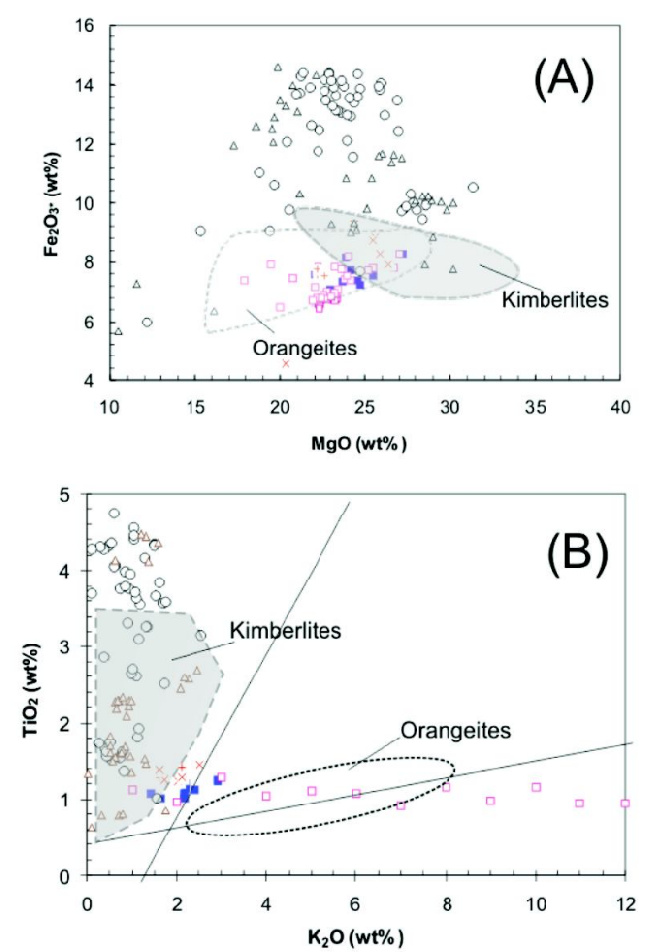

Figure 2 (A) Whole-rock variations of (A) $\mathrm{MgO}$ (wt $\%$ ) versus $\mathrm{Fe}_{2} \mathrm{O}_{3}$ * (wt\%) and $(\mathrm{C}) \mathrm{K}_{2} \mathrm{O}\left(\mathrm{wt} \%\right.$ ) versus $\mathrm{TiO}_{2}(\mathrm{wt} \%$ ) for the Mainpur pipes (filled circles). Kimberlite and orangeite fields are from Donnelly et al., 2011 and the references therein. Open circles, squares and triangles are the data for kimberlites from the Dharwar craton, southern India (after Chalapathi Rao et al., 2004; Chalapathi Rao and Srivastava, 2009; Chalapathi Rao and Dongre, 2009; Chalapathi Rao et al., 2011b).

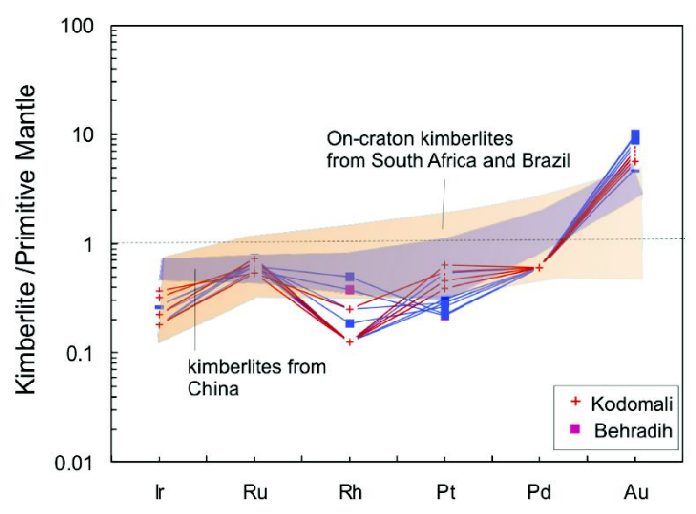

Figure 3 Primitive mantle-normalized (after Barnes et al., 1988) PGE and $\mathrm{Au}$ diagram for Behradih and Kodomali orangeites (this study) compared with those from on-craton kimberlites from South Africa and Brazil (McDonald et al., 1995) and China (Zhang et al., 2010). pipes is predominated by calcic lherzolitic variety with $<5 \%$ belong to high interest sub-calcic harzburgitic category and rest to other fields such as eclogitic types (Fig.4). The lherzolitic trend is suggestive of garnets in equilibrium with clinopyroxene (see Gibson et al., 2008) which is consistent with the garnet-peridotite affinities of the Mainpur diopside xenocrysts. The findings of our study are also consistent with those reported earlier by (i) Jha et al., (2002) wherein pyrope population in the Mainpur pipes has been inferred to be dominated by calcic-lherzolite variety corresponding to G9 and some eclogitic (G3, G4 and G5) and iron-titanian-low calcium (G1 and G2) garnets with the sub-calcic harzburgitic category (G10) pyrope garnet population between 1 and 5\% and (ii) Mukherjee et al., (2000) who reported garnets of eclogitic paragenesis from the Behradih pipe.
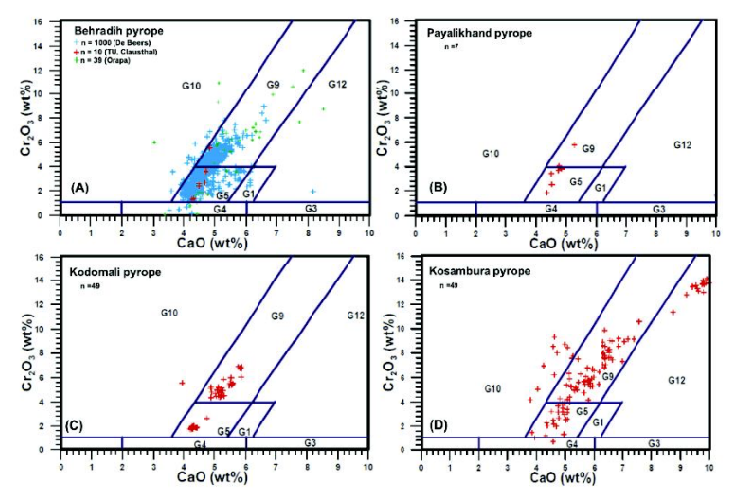

Figure $4 \mathrm{~A}-\mathrm{D} \mathrm{Cr} \mathrm{O}_{3}$ vs $\mathrm{CaO}$ (wt $\%$ ) variation plots of pyrope garnet separates from orangeites of this study. The fields are adopted from Grutter et al., (2004)

The presence of "sinusoidal" $\mathrm{REE}_{\mathrm{N}}$ patterns in garnets of this study (Fig.5) is significant since such patterns are regarded to be resultants of two stage process involving an (i) initial extensive komatiite melt extraction event which result in extreme LREE and HREE depletion leading to a depleted lithosphere followed by (ii) a second stage involving fluid metasomatism wherein repeated pulses of fractionated melt with low 


\section{$10^{\text {th }}$ International Kimberlite Conference, Bangalore - 2012}

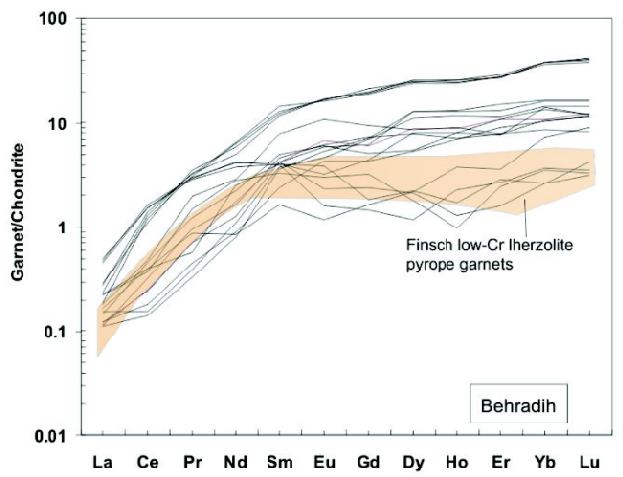

Figure 5 Chondrite-normlized Rare-earth element distribution patterns for pyrope garnet separates from Behraidh orangeite. The field of Finsch low-Cr lherzolite pyropes, shown for comparison, is from Gibson et al., (2008).

HREE and variable LREE/MREE into the already depleted lithosphere (Stachel et al., 2004; Creighton et al., 2010). The sub-calcic harzburgitic garnets displaying sinusoidal $\mathrm{REE}_{\mathrm{N}}$ are only confined to depths $<175 \mathrm{~km}$ and temperatures of $1150^{\circ} \mathrm{C}$ where as lherzolitic garnets and Ti-rich pyrope megacrysts originate from depths in excess of $175 \mathrm{~km}$ (e.g., Stachel et al., 2004; Lehtonen, 2005). Therefore the present study identifies, for the first time, the presence of a compositionally layered mantle in the endCretaceous sub-Bastar craton similar to that reported from other cratons elsewhere such as Kaapvaal craton (e.g., Gregoire et al., 2003; Gibson et al., 2008) western Guyana shield ( e.g., Schulze et al., 2006), Slave craton (e.g., Griffin et al., 1999; Kopylova and Caro, 2004), Siberian craton (e.g., Ashchepkov et al., 2010), North Atlantic craton (Sand et al., 2009) and Karelian craton (Lehtonen et al., 2004).

Some of the chromites from the Behradih Kodomali and Kosambura pipes are compositionally similar to those found as inclusions in diamonds (Fig.6) implying their derivation from a diamond stability field, which also additionally finds support from the diamondiferous nature of these pipes.

Oxygen fugacity $\left(\mathrm{fO}_{2}\right)$ estimates based on perovskite oxybarometry (Canil and Bellis, 2007)

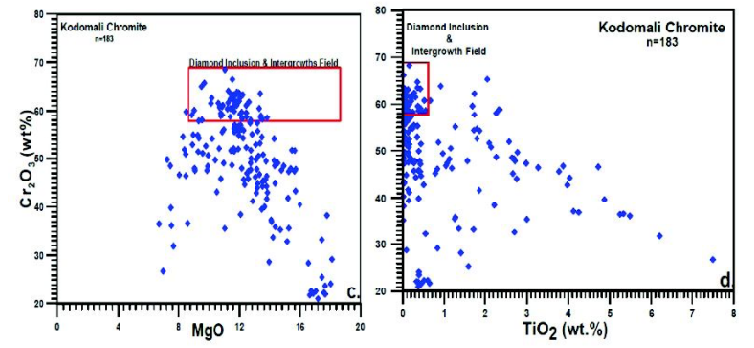

Figure $6 \mathrm{Cr}_{2} \mathrm{O}_{3}(\mathrm{wt} \%)$ versus $\mathrm{MgO}(\mathrm{wt} \%)$ and $\mathrm{Cr}_{2} \mathrm{O}_{3}(\mathrm{wt} \%)$ versus $\mathrm{TiO}_{2}(\mathrm{wt} \%)$ variation plots of Kodomali chromite xenocrysts. Diamond inclusion and intergrowth field is after Fipke et al., (1995).

highlight that (i) the ÄNNO conditions of the Mainpur pipes are higher from those from nonprospective NKF pipes as well as other prospective diamondiferous kimberlites located elsewhere such as Dutoitspan, southern Africa, Somerset Island, Canada and (ii) are indistinguishable in the redox conditions of the highly diamondiferous Lac de Gras kimberlites, Canada (Fig.7). We therefore conclude that oxidation state cannot explain the high incidence of diamonds in the Mainpur field and other factors very likely have played a significant role. The Mainpur orangeites are thus indeed "anomalous"

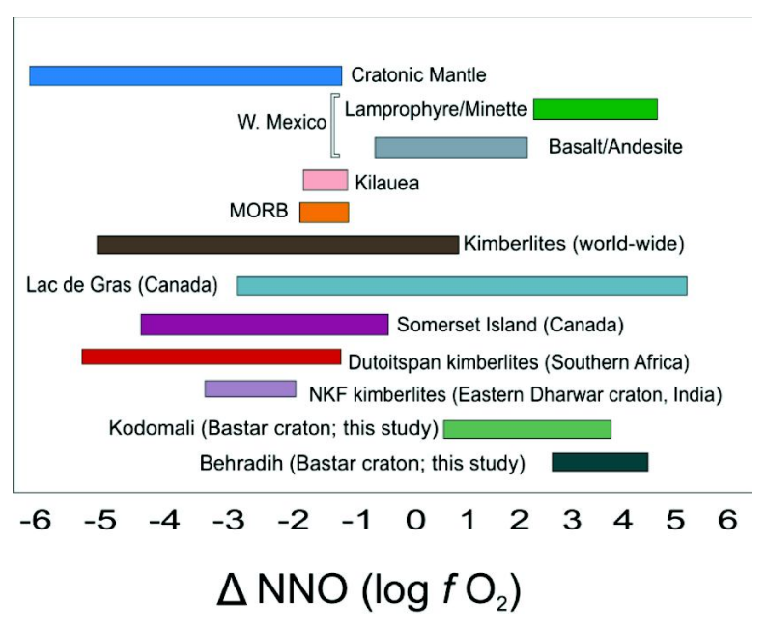

Figure 7 Oxygen fugacity $\left(f \mathrm{O}_{2}\right)(\Delta \mathrm{NNO})$ conditions of the Behradih and Kodomali orangeites compared with those recorded by cratonic mantle lithosphere, mantle-derived magmas and global kimberlites (adapted from Canil and Bellis, 2007). Data for Dutoitspan kimberlites is from Ogilvie-Harris et al., (2009); NKF kimberlites (Chalapathi Rao et al., 2011b). 


\section{0 $^{\text {th }}$ International Kimberlite Conference, Bangalore - 2012}

in terms of their high diamond incidence considering the preponderance of calciclherzolitic garnets and high oxidising conditions available at the time of their eruption.

All the zircons recovered from the Behradih pipe are crustal-derived xenocrysts, and not mantle-derived megacrysts, as revealed by their composition and U-Pb ages (Fig.8). However, paucity of Archaean age in any of the dated grains is surprising since Bastar craton is regarded as the oldest continental nuclei in the Indian shield

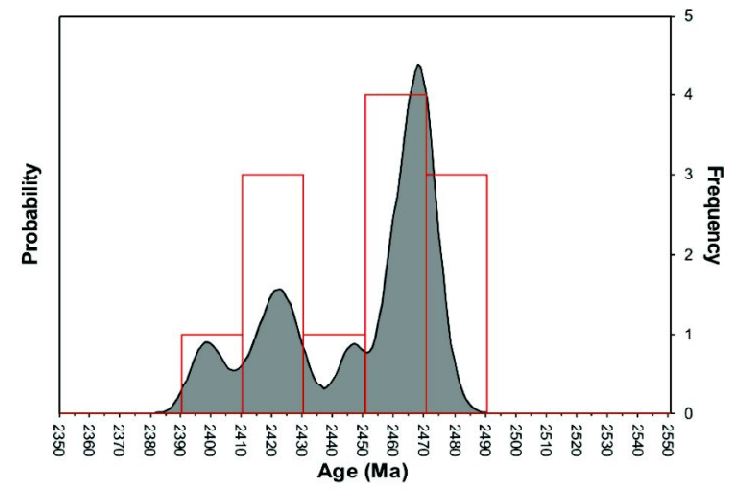

Figure 8 Frequency plot of the U-Pb zircon ages from the Behradih pipe. Lack of zircons of Archaean zircons is striking.

with an Eoarchaean crust as evidenced by the 3.50-3.6 Ga zircons from the exposed tonalities and granites (Sarkar et al., 1993) and a thickened modern-day crust of 35-40 km (Jagdeesh and Rai, 2008). Therefore, non-recovery of Archaean aged zircons could well be a reflection of the sampling. Alternately, it may also represent modification of the sub-Bastar lithosphere by the invading Deccan plume-derived melts during the end-Cretaceous synchronous with the eruption of the Mainpur orangeites (see Chalapathi Rao and Lehmann, 2011 for a detailed discussion). Further studies involving the $\mathrm{U}-\mathrm{Pb}$ dating of zircons from the Mainpur field is expected to provide further clues in this direction.

\section{References}

ASHCHEPKOV I .V., POKHILENKO N.P., VLADYKIN, N.V., LOGVINOVA, A.M.,
AFANASIEV, V.P., POKHILENKO, L. N., KULIGIN, S., MALYGINA, E.V., ALYMOVA, N.A., KOSTROVITSKY, S.I, ROTMAN, A.Y., MITYUKHIN. S.I., KARPENKO, M.A., STEGNITSKY, Y.B, KHEMELNIKOVA, O.S., (2010) Structure and evolution of the lithospheric mantle beneath Siberian craton, thermobarometric study.Tectonophysics, v.485, pp. 17-41.

BARNES, S.J. et al (1988) The use of mantle normalization and metal ratios in discriminating between the effects of partial melting, crystal fractionation and sulphide segregation on platinumgroup elements, gold, nickel and copper: Examples from Norway. In Geoolatinum 87 (ed. H. M. Pritchard et al.). .U .D . 113-143, Elsevier.

CANIL, D. and BELLIS, A.J.(2007). Ferric iron in $\mathrm{CaTiO}_{3}$ perovskite as an oxygen barometer for kimberlite magmas II. Applications. Journal of Petrology v.48, pp.231-252.

CHALAPATHI RAO, N.V. and DONGRE, A. (2009). Mineralogy and geochemistry of kimberlites NK2 and KK-6, Narayanpet kimberlite field, Eastern Dharwar craton, southern India: evidence for a transitional (South African) kimberlite signature. Canadian Mineralogist v.47, pp.855-873.

CHALAPATHI RAO, N.V. AND SRIVASTAVA, R.K. (2009). Petrology and Geochemistry of Diamondiferous Mesoproterozoic kimberlites from Wajrakarur Kimberlite Field, Eastern Dharwar Craton, Southern India: Genesis and constraints on mantle source regions. Contributions to Mineralogy and Petrology v.157, pp.245-265.

CHALAPATHI RAO, N.V. and LEHMANN, B (2011) Kimberlites, flood basalts and mantle plumes: new insights from the Deccan Large Igneous Province. Earth-Science Reviews 107, 315-324.

CHALAPATHI RAO, N.V., GIBSON, S.A., PYLE, D.M. and DICKIN, A.P. (2004) Petrogenesis of Proterozoic lamproites and kimberlites from the Cuddapah Basin and Dharwar craton, southern India. Journal of Petrology v.45(5), pp. 907-948.

CHALAPATHI RAO, N.V., LEHMANN, B., MAINKAR, D. and BELYATSKY, B., (2011a). Petrogenesis of the end-Cretaceous diamondiferous Behradih orangeite pipe: implication for mantle plume - lithosphere interaction in the Bastar craton, 


\section{0 $^{\text {th }}$ International Kimberlite Conference, Bangalore - 2012}

Central India. Contributions to Mineralogy and Petrology v. 161, pp. 721-742.

CHALAPATHI RAO, N.V., PATON, C. and LEHMANN, B. (2011b) Origin and diamond prospectivity of the Mesoproterozoic kimberlites from the Narayanpet field, Eastern Dharwar craton, southern India: insights from groundmass mineralogy, bulk-chemistry and perovskite oxybarometry. Geological Journal (In Press) DOI: 10.1002/gj.1309.

CHATTERJEE, B,. and JHA, N., (1994) Diamondiferous kimberlitic diatremes of Payalikhand, Behradih and Jangra, Raipur district, Madhya Pradesh. Records of the Geological Survey of India v.127(6), pp.240-243.

COE, N., LE ROEX, A.P., GURNEY, J., PEARSON, G. and NOWELL, G. (2008). Petrogenesis of the Swartruggens and Star Group II kimberlite dyke swarms, South Africa: constraints from whole rock geochemistry. Contributions to Mineralogy and Petrology, v. 156, pp. 627-652.

FAREEDUDDIN, PANT, N.C. and NEOGI, S., (2006) Petrology of the Kodomali diatreme, Mainpur area, Chhattisgarh, Central India: implications for a Palaeozoic orangeite field. Journal of the Geological Society of India v.68, pp. 19-34.

FIPKE, C.E., GURNEY, J.J. and MOORE, R.O. (1995) Diamond exploration techniques emphasising indicator mineral geochemistry and Canadian examples. Geol. Survey of Canada Bull., v.423, $86 \mathrm{pp}$.

FRASER, K.J. and HAWKESWORTH, C.J., (1992) The petrogenesis of group2 ultrapotassic kimberlites from the Finsch Mine, South Africa. Lithos v.28, pp.327-345.

GIBSON, S.A., MALARKEY, J. and DAY, J., (2008) Melt Depletion and Enrichment beneath the Western Kaapvaal Craton: Evidence from Finsch Peridotite Xenoliths. Journal of Petrology, v.49, pp. 1817-1852.

GREGOIRE, M. and BELL, D.R. and LE ROEX, A.P. (2003) Garnet lherzolites from the Kaapvaal Craton (South Africa): Trace element evidence for a metasomatic history. Journal of Petrology v.44, pp.629-657.

GRIFFIN, W.L., SHEE, S.R., RYAN, C.G., WIN, T.T., and WYATT, (B.A). 1999. Harzburgite to lherzolite and back again: Metasomatic processes in ultramafic xenoliths from the Wesselton kimberlite, Kimberley, South Africa. Contributions to Mineralogy and Petrology v.134, pp.232-250.

GRUTTER, H.S., GURNEY, J.J., MENZIES, A.H. and WINTER, F., (2004) An updated classification scheme for mantle-derived garnet, for use by diamond explorers. Lithos v.77, pp. 841-857.

HOWARTH, G.H., SKINNER, E.M.W. and PREVEC S.A. (2011) Petrology of the hypabyssal kimberlite of the Kroonstad group II kimberlite (orangeite) cluster, South Africa: Evolution of the magma within the cluster. Lithos v.125, 795-808.

JAGADEESH, S, and RAI, S.S. (2007) Thickness, composition and evolution of the Indian Precambrian crust inferred from broadband seismological measurements. Precambrian Research v.16, pp. 4-15.

JHA, N., CHATTERJEE, B., MISHRA, B.K., SARKAR, S.K., (2002) Kimberlites of Mainpur kimberlite field, Raipur district, Chhattisgarh, central India. In: Abstracts volume of the International Conference on Diamonds and Gemstones, Raipur.

KJARSGAARD, B.A., HARVEY, S., McCLINTOCK, M., ZONNEVELD, J.P., DU PLEISSIS, P:; McNEIL, D. and HEAMAN, L., (2009) Geology of the Orion South kimberlite, Fort à la Corne, Canada. Lithos v.112, pp.600-617.

KOPYLOVA M.G. and CARO G.,( 2004). Mantle xenoliths from the Southeastern Slave craton: The evidence for a thick cold stratified lithosphere. Journal of Petrology v.45, pp.1045106.

LEHMANN, B., BURGESS, R., FREI, D., BELYATSKY, B., MAINKAR, D., CHALAPATHI RAO, N.V. and HEAMAN, L.M., (2010) Diamondiferous kimberlites in central India synchronous with Deccan flood basalts. Earth and Planetary Science Letters v.290, pp.142-149.

LEHTONEN, M.L., O'BRIEN, H.E., PELTONEN, P., JOHNSON, B.S. and PAKKANEN, L.K., (2004) Layered mantle at the Karelian craton margin: P-T of mantle xenocrysts from the Kaavi-Kuopio kimberlites, Finland. Lithos v.77, 593-608.

LEHTONEN, M.L, (2005) Rare earth element characteristics of pyrope garnets from the KaaviKuopio kimberlites- implications for mantle metasomatism. Bulletin Geological Society of 
Finland, v.77, pp. 31-47.

MCDONALD, I., DE WIT, M.J., SMITH, C.B., BIZZI, L.A. and VILJOEN, K.S. (1995) The geochemistry of the Platinum Group of elements in Brazilian and southern African kimberlites. Geochmica et Cosmochimica Acta, v. 59, pp. 2882-2903.

MITCHELL, R.H. (1995) Kimberlites, orangeites and related rocks. Plenum press, New York, 406pp.

MITCHELL, R.H. (2006) Potassic magmas derived from metasomatised lithospheric mantle: nomenclature and relevance to exploration for diamond-bearing rocks. Journal of the Geological Society of India v. 67(3), pp. 317-327.

MITCHELL, R.H. and FAREEDUDDIN (2009) Mineralogy of peralkaline lamproites from the Raniganj Coalfield, India. Mineralogical Magazine v.73, pp.457-477.

MUKHERJEE, A., TRIPATHI, A., SINGH, P.K. and BABU, E.V.S.S.K.,(2000) Chemistry of eclogitic garnets from Behradih kimberlite, Raipur district, Madhya Pradesh. Journal of the Geological Society of India v.56, pp.425-430.

OGILVE-HARRIS, R.C., FIELD, M., SPARKS, R.S.J. and WALTER, M.J. (2009). Perovskite from Dutoitspan kimberlite, Kimberley, South Africa: implications for magmatic processes. Mineralogical Magazine v.73, pp.915-928.
SARKAR, G., CORFU, F., PAUL, D.K., McNAUGHTON. N.J., GUPTA, S.N. and BISHUI, P.K. (1993) Early Archean crust in Bastar Craton, Central India-a geochemical and isotopic study. Precambrian Research v. 62, pp. 127-137.

SCHULZE, D.J., CANIL, D., CHANNER, D.M.DER. and KAMINSKY, F. (2006) Layered mantle structure beneath the western Guyana Shield, Venezuela: Evidence from diamonds and xenocrysts in Guaniamo kimberlites. Geochimica et. Cosmochimica Acta, v. 70, pp. 192-205.

SMITH,C.B. (1983) Pb, Sr and Nd isotopic evidences for sources of southern African Cretaceous kimberlites. Nature, v. 304, pp. 51-54.

STACHEL, T., AULBACH, S., BREY, G.P., HARRIS, J.W., LEOST, I., TAPPERT, R. and VILJOEN, K.S. (2004). The trace element composition of silicate inclusions in diamonds: a review. Lithos, v.77, pp.1-19.

WAGNER, P.A. (1914). The Diamond fields of South Africa. Transvaal Leader, Johannesburg, South Africa.

ZHANG, H.F., Zhou, M.F., SUN, M. and Zhou, X.H., (2010) The origin of Mengyin and Fuxian diamondiferous kimberlites from the North China Craton: Implication for Palaeozoic subducted oceanic slab-mantle interaction. Journal of Asian Earth Sciences v.37, pp. 425-437. 